\title{
ANALISIS ANTUSIASME SISWA DALAM EVALUASI BELAJAR MENGGUNAKAN PLATFORM QUIZIZZ
}

\author{
Lailatul Asria $^{*}$ (D) , Dwi Ratna Sari2 ${ }^{\text {iD }}$, Siti Anifatul Ngaini3 ${ }^{\text {ID }}$, Umi \\ Muyasaroh4 $^{\text {iD }}$, Fadhilah Rahmawatis \\ Program Studi Pendidikan Matematika, Universitas Tidar Magelang, Indonesia \\ 1* $\underline{\text { lailatulasriya112@gmail.com, }}{ }^{2}$ ratnasari.0611@gmail.com, \\ 3isianifatulngaini@gmail.com, ${ }^{4}$ umimuymuy@gmail.com, \\ 5fadhilahrahmawati@untidar.ac.id
}

Received: December 15, $2020 \quad$ Revised: January 25, $2021 \quad$ Accepted: February 2, 2021

\begin{abstract}
:
One way to evaluate student learning outcomes is through question processing. However, nowadays evaluations are usually carried out using conventional methods such as a paper-based test. Even though often in the implementation of evaluations, students feel less enthusiastic about their work. This study aims to identify students' enthusiasm in solving questions through the Quizizz platform. The subjects of this study were 34 students of class XI Science 4 Senior High School 1 Tahunan. This research uses a descriptive quantitative method because shows a description of the students' enthusiasm for using the Quizizz platform as a tool for solving trigonometric questions. To analyze the enthusiasm of students in solving questions through the Quizizz platform, was carried out in three stages: 1) distributing a questionnaire with 25 question items via Google Form based on five indicators that measure enthusiasm (Response, attention, concentration, willingness, and self-involvement), 2) questionnaire data analyzed based on the answer score for each question item. Based on the research results, student enthusiasm in learning evaluation on trigonometric material through the Quizizz platform got a percentage of $62.38 \%$. So that the Quizizz platform can be an alternative for teachers in evaluating student learning outcomes to create an atmosphere of evaluation that is fun and interesting for students to follow which will increase student enthusiasm in participating in learning evaluations.
\end{abstract}

Keywords: trigonometry, evaluation, enthusiasm, Quizizz platform.

How to Cite: Asria, L., Sari, D. R., Ngaini, S. A., Muyasaroh, U., Rahmawati, F. (2021). Analisis Antusiasme Siswa dalam Evaluasi Belajar Menggunakan Platform Quizizz. Alifmatika: Jurnal $\begin{array}{lllll}\text { Pendidikan dan } \quad \text { Pembelajaran } & \text { 3(1), }\end{array}$ https://doi.org/10.35316/alifmatika.2021.v3i1.1-17

\section{PENDAHULUAN}

Pada kegiatan pembelajaran, tahap pengerjaan soal merupakan salah satu cara mengevaluasi hasil belajar siswa. Evaluasi dapat diartikan sebagai proses sistematis untuk menentukan nilai sesuatu (ketentuan, keputusan, unjuk-kerja, proses, orang, objek dan lainnya) berdasarkan kriteria tertentu melalui penilaian. Evaluasi dapat mendorong siswa untuk lebih giat belajar dan mendorong guru untuk lebih meningkatkan kualitas proses pembelajaran serta mendorong sekolah untuk lebih meningkatkan fasilitas dan kualitas belajar siswa. Sehubungan dengan 
hal tersebut, optimalisasi sistem evaluasi memiliki dua makna. Pertama adalah sistem evaluasi yang memberikan informasi yang optimal. Kedua, evaluasi dapat meningkatkan kualitas pembelajaran dan selanjutnya akan terjadi peningkatan kualitas pendidikan (Mahirah, 2017: 257). Evaluasi dianggap penting, karena dengan evaluasi, seorang pengajar dapat mengetahui apakah siswa mampu menguasai materi yang telah diajarkan, apakah mereka bersikap sebagaimana yang diajarkan, apakah mereka telah memiliki keterampilan, mengetahui keberhasilan proses belajar mengajar yang telah dilaksanakan, dan menentukan kebijakan selanjutnya. Maka dari itu, evaluasi tidak dapat dipisahkan dari pembelajaran, sehingga guru mau tidak mau harus melakukan evaluasi pembelajaran (Elis Ratna Wulan \& Rusdiana, 2015).

Evaluasi merupakan proses terakhir dalam pembelajaran yang bertujuan untuk mengukur dan mengetahui hasil belajar dan sejauh mana pemahaman konsep siswa terhadap materi yang diajarkan. Selama ini guru melakukan penilaian hasil belajar atau tes hasil belajar siswa menggunakan cara konvensional yaitu berbasis kertas (paper based test) (Abi, 2016: 39). Secara psikologis paper based test dapat menimbulkan kecemasan siswa (Kuncahyono, Suwandayani, \& Muzakki, 2020: 158). Hal ini dikarenakan kondisi pengawas yang ada di sekitar siswa membuat suasana yang mencemaskan bagi siswa. Selain itu, soal dari percetakan atau fotokopi terkadang masih ada yang kualitasnya rendah, kurang menarik, buram, dan terdapat tulisan yang kurang jelas akibat kesalahan teknis dalam penggandaan soal (Abi, 2016: 39). Permasalahan ini tentu menjadi tantangan bagi guru untuk menciptakan suasana evaluasi belajar yang menyenangkan serta menarik siswa dalam pengerjaannya. Maka dari itu, diperlukan sarana evaluasi yang sejalan dengan penciptaan suasana yang menarik dan menyenangkan, seperti halnya evaluasi belajar menggunakan game atau permainan. Salah satu dampak positif penggunaan game dalam pembelajaran adalah game menyenangkan dan menghibur serta game memberikan latihan untuk pemecahan masalah dan logika (Henry, 2010: 53-54). Sebagai solusi dalam mengatasi permasalahan ini, peneliti memilih platform Quizizz.

Quizizz adalah situs online yang membantu siswa memeriksa pengetahuan dan kemajuan dalam pembelajaran mereka (Rahayu \& Purnawarman, 2019). Pembelajaran berbasis permainan ini dapat dikerjakan dalam mode langsung tatap muka di ruangan kelas atau dapat juga diberikan sebagai pekerjaan rumah untuk siswa. Hal ini dianggap sangat memungkinkan karena Quizizzz mudah diakses melalui web. Siswa hanya perlu diberikan link dan game pin, di mana setelah itu siswa dapat menyelesaikannya di manapun mereka berada. Quizizz merupakan aplikasi pendidikan berbasis game, yang membawa aktivitas multi pemain ke ruang kelas dan membuat pembelajaran di kelas menjadi interaktif serta menyenangkan (Purba, 2020). Penggunaan Quizizz dalam evaluasi belajar dapat diterapkan pada materi apa saja. Namun dalam penelitian ini, peneliti menggunakan materi trigonometri sebagai bahan yang akan digunakan dalam melaksanakan penelitian, karena trigonometri merupakan salah satu materi yang sulit dikuasai oleh sebagian besar siswa (Putra \& Anggraini, 2016: 40).

Penggunaan Quizizz dianggap efektif serta menjadikan siswa lebih aktif, selain itu penggunaan Quizizz sejalan dengan perkembangan zaman yang menggunakan multimedia interaktif berbasis smartphone dengan perbedaan yang 
signifikan dibandingkan media konvensional. Hal ini didasarkan pada penelitian (Purba, 2020) menunjukkan bahwa Quizizz sebagai media evaluasi pembelajaran online dianggap efektif terhadap siswa. Selain itu, dalam penelitian yang dilakukan (Ju \& Adam, 2018) menyatakan bahwa implementasi penggunaan Quizizz menjadikan siswa lebih aktif untuk menjawab pertanyaan yang diberikan dan membantu siswa meningkatkan keterampilan dan lebih konsentrasi pada topik. (Wihartanti, Wibawa, Astuti, \& Pangestu, 2019) juga mengatakan bahwa terdapat perbedaan yang signifikan antara kelas yang menggunakan multimedia interaktif berbasis smartphone dibandingkan kelas yang menggunakan model konvensional. Sehingga, aplikasi Quizizz berbasis smartphone dapat lebih meningkatkan kemampuan berpikir. Oleh karena itu, peneliti melakukan penelitian guna mengetahui kategori antusiasme siswa dalam mengerjakan soal dengan Quizizz khususnya pada materi trigonometri.

Berdasarkan uraian penelitian tersebut, maka perlu diadakan penelitian lebih lanjut terkait antusiasme siswa dalam penggunaan Quizizz sebagai media evaluasi pembelajaran dengan indikator respon, perhatian, konsentrasi, kemauan, dan kesadaran untuk melibatkan diri (Afdhal, 2015: 196). Penelitian ini menggunakan materi yang berbeda dengan peneliti sebelumnya yaitu materi trigonometri. Oleh karena itu, tujuan dari penelitian ini adalah untuk menganalisis antusiasme siswa dalam evaluasi belajar menggunakan Quizizz pada evaluasi pembelajaran trigonometri.

\section{METODE PENELITIAN}

Penelitian ini dilakukan untuk menganalisis taraf antusiasme siswa dalam pengerjaan soal matematika dengan platform Quizizz pada materi trigonometri di SMA Negeri 1 Tahunan Jepara. Metode yang digunakan dalam penelitian ini adalah metode penelitian deskriptif kuantitatif karena menunjukkan adanya deskripsi antusiasme siswa terhadap penggunaan platform Quizizz sebagai alat pengerjaan soal Trigonometri. Menurut Tiwijayanti \& Pramono (2020: 106) digunakan metode kuantitatif agar dapat menjelaskan situasi yang hendak diteliti berdasarkan hasil angket untuk lebih memperkuat analisa peneliti dalam membuat kesimpulan. Populasi dalam penelitian ini adalah seluruh siswa kelas XI MIPA 4 SMA Negeri 1 Tahunan Jepara tahun ajaran 2020/2021 yang berjumlah 34 siswa. Teknik pengambilan sampel yaitu total sampling, di mana jumlah sampel sama dengan jumlah populasi (Kurniawan \& Prastowo, 2017: 110).

Materi yang dipilih untuk penelitian penggunaan Quizizz sebagai alat evaluasi yaitu materi trigonometri. Pada penelitian ini, data diperoleh melalui angket sebagai data utama. Angket yang digunakan dalam penelitian ini adalah angket tertutup yang terdiri dari 25 item pertanyaan yang disusun oleh peneliti berdasarkan lima indikator yaitu respon, perhatian, konsentrasi, kemauan, dan kesadaran untuk melibatkan diri (Afdhal, 2015). Pembentukan angket pada penelitian ini menggunakan skala linkert dengan lima kategori jawaban yaitu sangat setuju, setuju, netral, tidak setuju, dan sangat tidak setuju.

Angket antusiasme siswa divalidasi oleh dosen ahli dan diujicobakan kepada siswa sebelum digunakan untuk penelitian. Validitas dimaksudkan untuk melihat 
kesesuaian butir pernyataan angket dengan indikator antusiasme siswa dan susunan kalimat. Setelah dilakukan validitas isi, angket diujicobakan kepada 10 siswa kelas XI MIPA 4 SMA Negeri 1 Tahunan untuk mengetahui reliabilitas angket. Reliabilitas angket antusiasme siswa ditentukan apabila koefisien reliabilitas $\left(r_{11}\right)$ $\geq 0,70$ maka butir soal yang diujikan memiliki reliabilitas yang tinggi atau reliabel, tetapi apabila $r_{11} \leq 0,70$ maka butir soal yang diujikan memiliki reliabilitas rendah atau tidak reliabel (Salmina \& Adyansyah, 2017: 45).

Teknik analisis data yakni menghitung hasil angket seberapa antusiasme siswa mengerjakan soal matematika terutama dalam materi trigonometri menggunakan Quizizz. Setelah data angket terkumpul kemudian data tersebut dianalisis dengan menggunakan analisis deskriptif kuantitatif. Hasil angket akan diberi skor jawaban untuk tiap item pertanyaan. Penentuan skor dari jawaban angket tersebut berdasarkan skala dari pemilihan jawaban. Adapun kriteria pemberian skor dapat dilihat pada Tabel 1.

Tabel 1. Skor jawaban angket

\begin{tabular}{cccccc}
\hline \multirow{2}{*}{$\begin{array}{c}\text { Sifat } \\
\text { Pernyataan }\end{array}$} & $\begin{array}{c}\text { Sangat } \\
\text { Setuju (SS) }\end{array}$ & $\begin{array}{c}\text { Setuju } \\
\text { (S) }\end{array}$ & $\begin{array}{c}\text { Netral } \\
\text { (N) }\end{array}$ & $\begin{array}{c}\text { Tidak } \\
\text { Setuju (TS) }\end{array}$ & $\begin{array}{c}\text { Sangat Tidak } \\
\text { Setuju (STS) }\end{array}$ \\
\hline Positif & 4 & 3 & 2 & 1 & 0 \\
\hline Negatif & 0 & 1 & 2 & 3 & 4 \\
\hline
\end{tabular}

Hasil angket yang telah diberikan skor, selanjutnya dianalisis secara deskriptif persentase. Antusiasme siswa dikategorikan menjadi antusiasme sangat tinggi, tinggi, sedang, rendah, dan sangat rendah. Setelah itu ditentukan persentasenya untuk mengetahui tingkatan antusiasme siswa secara umum ketika pengerjaan soal trigonometri melalui platform Quizziz dengan menggunakan rumus sebagai berikut:

$$
\frac{\text { nilai jumlah skor sesuai kategori }}{\sum \text { keseluruhan nilai skor }} \times 100 \%
$$

(Tiwijayanti \& Pramono, 2020: 108).

Hasil analisis tersebut digunakan untuk mengetahui tingkat antusiasme siswa dalam evaluasi belajar melalui platform Quizizz yang dinyatakan dalam kategori antusiasme sangat tinggi, tinggi, sedang, rendah, dan sangat rendah. Selain menghitung persentase antusiasme berdasarkan kategori, dapat dihitung persentase antusiasme berdasarkan tiap indikator. Adapun cara menghitung persentase tiap indikator dari angket antusiasme siswa adalah sebagai berikut:

$$
M=\frac{X}{Y} \times 100 \%
$$


$\mathrm{M}$ = Persentase indikator antusiasme siswa (respon, perhatian, konsentrasi, kemauan, kesadaran dan keterlibatan diri) dalam pengerjaaan soal matematika menggunakan platform Quizizz dari hasil jawaban responden.

$\mathrm{X}=$ Skor dari indikator (respon, perhatian, konsentrasi, kemauan, kesadaran dan keterlibatan diri) dari hasil jawaban responden.

$\mathrm{Y}=$ Skor ideal dari indikator (respon, perhatian, konsentrasi, kemauan, kesadaran dan keterlibatan diri) (Sari, Sunarno, \& Sarwanto, 2018).

Kemudian, berdasarkan hasil perhitungan dalam bentuk persentase diinterpretasikan dengan kriteria deskriptif persentase dengan menggunakan interval jenjang kualitatif.

Tabel 2. Tabel Persentase Tanggapan Angket

\begin{tabular}{ll}
\hline \multicolumn{1}{c}{ Kategori } & \multicolumn{1}{c}{ Persentase } \\
\hline Sangat Tinggi & $85 \%<$ skor $\leq 100 \%$ \\
\hline Tinggi & $70 \%<$ skor $\leq 85 \%$ \\
\hline Sedang & $55 \%<$ skor $\leq 70 \%$ \\
\hline Rendah & $40 \%<$ skor $\leq 55 \%$ \\
\hline Sangat Rendah & $0 \%<$ skor $\leq 40 \%$
\end{tabular}

\section{HASIL DAN PEMBAHASAN}

Data hasil penelitian ini adalah data yang telah diperoleh dengan menggunakan metode angket. Angket yang dibagikan kepada siswa berisi 25 item pertanyaan dari lima indikator yang menjadi penilaian bahwa siswa memiliki taraf keantusiasan dalam pengerjaan soal trigonometri melalui platform Quizizz.

Angket antusiasme siswa divalidasi oleh validator ahli dan diujicobakan kepada 10 siswa kelas XI MIPA 4 SMA Negeri 1 Tahunan Jepara. Hasil dari uji reliabilitas untuk angket antusiasme belajar menunjukkan nilai reliabilitas (Cronbach's alpha) sebesar 0,768. Hasil tersebut menunjukkan bahwa nilai reliabilitas butir-butir angket yang disusun berdasarkan indikator antusiasme siswa masuk dalam kategori tinggi (reliable) sehingga angket tersebut siap digunakan sebagai instrumen penelitian.

Pada penelitian ini, hasil angket diperoleh dari seluruh siswa kelas XI MIPA 4 SMA Negeri 1 Tahunan Jepara Tahun ajaran 2020/2021 sebanyak 34 siswa. Angket dibagikan setelah siswa mengikuti evaluasi belajar pada materi trigonometri menggunakan platform Quizizz. Total skor dari jawaban angket kemudian dianalisis dan dikelompokkan menjadi antusiasme sangat tinggi, tinggi, sedang, rendah dan sangat rendah. 
Tabel 3. Nilai Yang Mengandung Unsur Positif

\begin{tabular}{lllc}
\hline No. & \multicolumn{1}{c}{ Jawaban } & \multicolumn{1}{c}{ Perhitungan Skor } & Nilai \\
\hline 1. & Sangat Setuju & $113 \times 4$ & 452 \\
\hline 2. & Setuju & $150 \times 3$ & 450 \\
\hline 3. & Netral & $214 \times 2$ & 428 \\
\hline 4. & Tidak Setuju & $28 \times 1$ & 28 \\
\hline 5. & Sangat Tidak Setuju & $10 \times 0$ & 0 \\
\hline
\end{tabular}

Tabel 4. Nilai Yang Mengandung Unsur Negatif

\begin{tabular}{lllc}
\hline No. & \multicolumn{1}{c}{ Jawaban } & \multicolumn{1}{c}{ Perhitungan Skor } & Nilai \\
\hline 1. & Sangat Setuju & $24 \times 0$ & 0 \\
\hline 2. & Setuju & $37 \times 1$ & 37 \\
\hline 3. & Netral & $151 \times 2$ & 302 \\
\hline 4. & Tidak Setuju & $79 \times 3$ & 237 \\
\hline 5. & Sangat Tidak Setuju & $49 \times 4$ & 196 \\
\hline
\end{tabular}

Tabel 5. Hasil Penjumlahan Nilai

\begin{tabular}{cccc}
\hline No. & Skor & Jumlah Skor & Nilai \\
\hline 1. & Skor 4 & $452+196$ & 648 \\
2. & Skor 3 & $450+237$ & 450 \\
3. & Skor 2 & $428+302$ & 730 \\
4. & Skor 1 & $28+37$ & 65 \\
5. & Skor 0 & $0+0$ & 0 \\
\hline \multicolumn{4}{r}{} \\
\hline
\end{tabular}

Tabel 6. Hasil Persentase

\begin{tabular}{rll}
\hline Skor & Hasil Persentase & Kategori \\
Skor 4 & $\frac{648}{1893} \times 100 \%=34 \%$ & Sangat Tinggi \\
\hline Skor 3 & $\frac{450}{1893} \times 100 \%=24 \%$ & Tinggi \\
\hline Skor 2 & $\frac{730}{1893} \times 100 \%=39 \%$ & Sedang \\
\hline Skor 1 & $\frac{65}{1893} \times 100 \%=3 \%$ & Rendah \\
\hline Skor 0 & $\frac{0}{1893} \times 100 \%=0 \%$ & Sangat Rendah \\
\hline
\end{tabular}




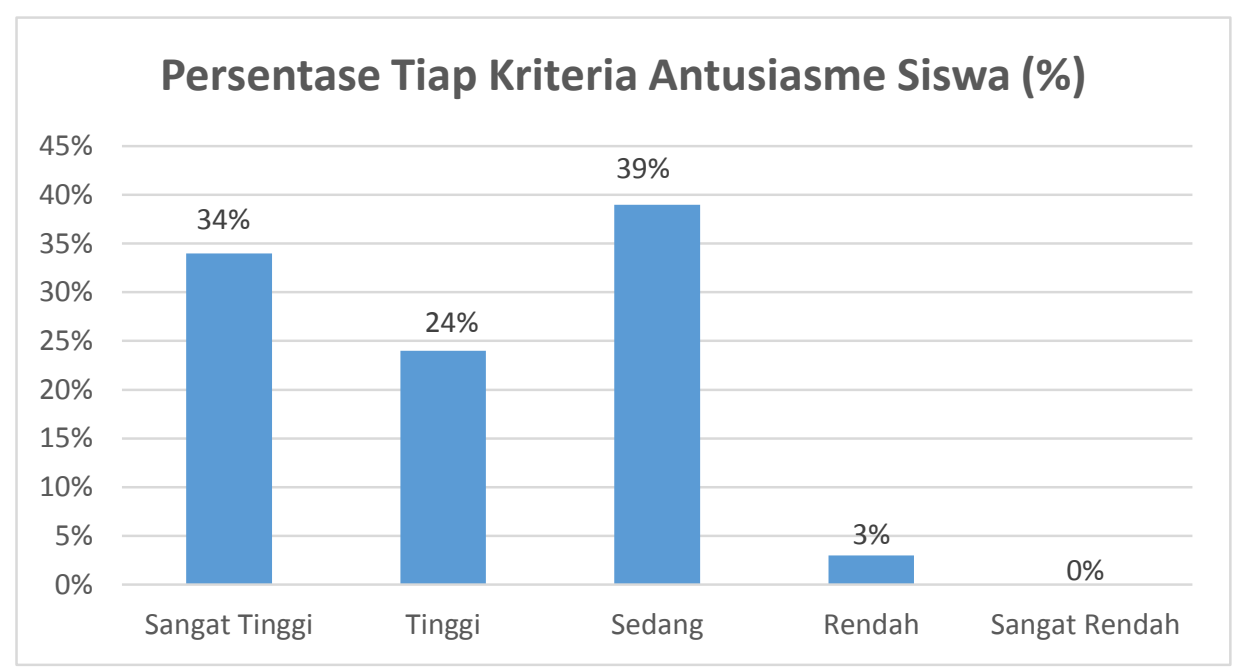

Gambar 1. Persentase Tiap Kriteria Antusiasme Siswa.

Hasil analisis data pada Gambar 1 tersebut menunjukkan bahwa hasil persentase untuk tiap kategori antusiasme siswa sebanyak 34\% siswa termasuk dalam kategori antusiasme sangat tinggi, 24\% siswa termasuk dalam kategori antusiasme tinggi, 39\% siswa termasuk dalam kategori sedang, serta 3\% siswa mempunyai antusiasme rendah. Diagram batang untuk menggambarkan masingmasing kategori antusiasme siswa pada pengerjaan soal trigonometri melalui platform Quizizz disajikan dalam gambar 1. Hasil penelitian yang ditunjukkan dalam Gambar 1 menjelaskan bahwa sebagian besar siswa SMA kelas XI MIPA 4 termasuk dalam kategori antusiasme sedang dalam pengerjaan soal trigonometri menggunakan platform Quizizz dengan persentase terbesar yaitu 39\%. Berdasarkan hasil analisis tersebut disebutkan bahwa jumlah siswa kelas XI MIPA 4 yang berjumlah 34 siswa, termasuk dalam kategori antusiasme sangat tinggi sebanyak 12 siswa, kategori antusiasme tinggi sebanyak 8 siswa, kategori sedang sebanyak 13 siswa, dan kategori rendah sebanyak 1 siswa. Jumlah siswa dengan kategori antusiasme yang dikelompokkan menjadi lima kategori disajikan dalam Tabel 7.

Tabel 7. Jumlah Siswa Menurut Pengelompokkan Antusiasme Siswa

\begin{tabular}{ccc}
\hline No. & Kategori Antusiasme Siswa & Banyak Siswa \\
\hline $\mathbf{1 .}$ & Sangat Tinggi & 12 \\
\hline $\mathbf{2 .}$ & Tinggi & 8 \\
\hline $\mathbf{3 .}$ & Sedang & 13 \\
\hline $\mathbf{4}$. & Rendah & 1 \\
\hline $\mathbf{5}$ & Sangat Rendah & 0 \\
\hline
\end{tabular}


Menurut Samuel (2015: 2017) antusiasme adalah pilihan dari perasaan yang muncul dan diseleksi kemudian dilanjutkan dan diperkuat, karena antusiasme dapat dihasilkan dari dalam diri kita sendiri atau keadaan di luar diri, antusiasme paling kuat adalah dari dalam diri, karena ketika kita telah memutuskan untuk memilih untuk menjadi antusias, maka akan dijalankan program dalam pikiran langsung menghasilkan energi. Berdasarkan analisis hasil angket, siswa memiliki perhatian yang cukup terhadap penggunaan Quizizz sebagai alat pengerjaan soal trigonometri. Menurut Putra \& Anggraini (2016: 40) materi trigonometri merupakan salah satu materi matematika yang sulit dikuasai oleh mayoritas siswa. Perhatian siswa yang cukup terhadap penggunaan Quizizz sebagai alat pengerjaan soal trigonometri tidaklah membuat siswa percaya diri dalam mengerjakan soal trigonometri. Hal ini diperkuat oleh hasil analisis angket yang menunjukkan bahwa indikator konsentrasi siswa memiliki persentase paling rendah di antara indikator yang lain. Siswa merasa kurang percaya diri dalam menjawab soal ketika menggunakan Quizizz dan merasa takut serta cemas akan hasil yang akan diterima sehingga siswa sulit untuk berkonsentrasi saat mengerjakan soal. Selain itu, waktu yang dibatasi untuk tiap butir soal pada Quizizz juga sangat mempengaruhi konsentrasi siswa untuk mengerjakan secara baik dan teliti.

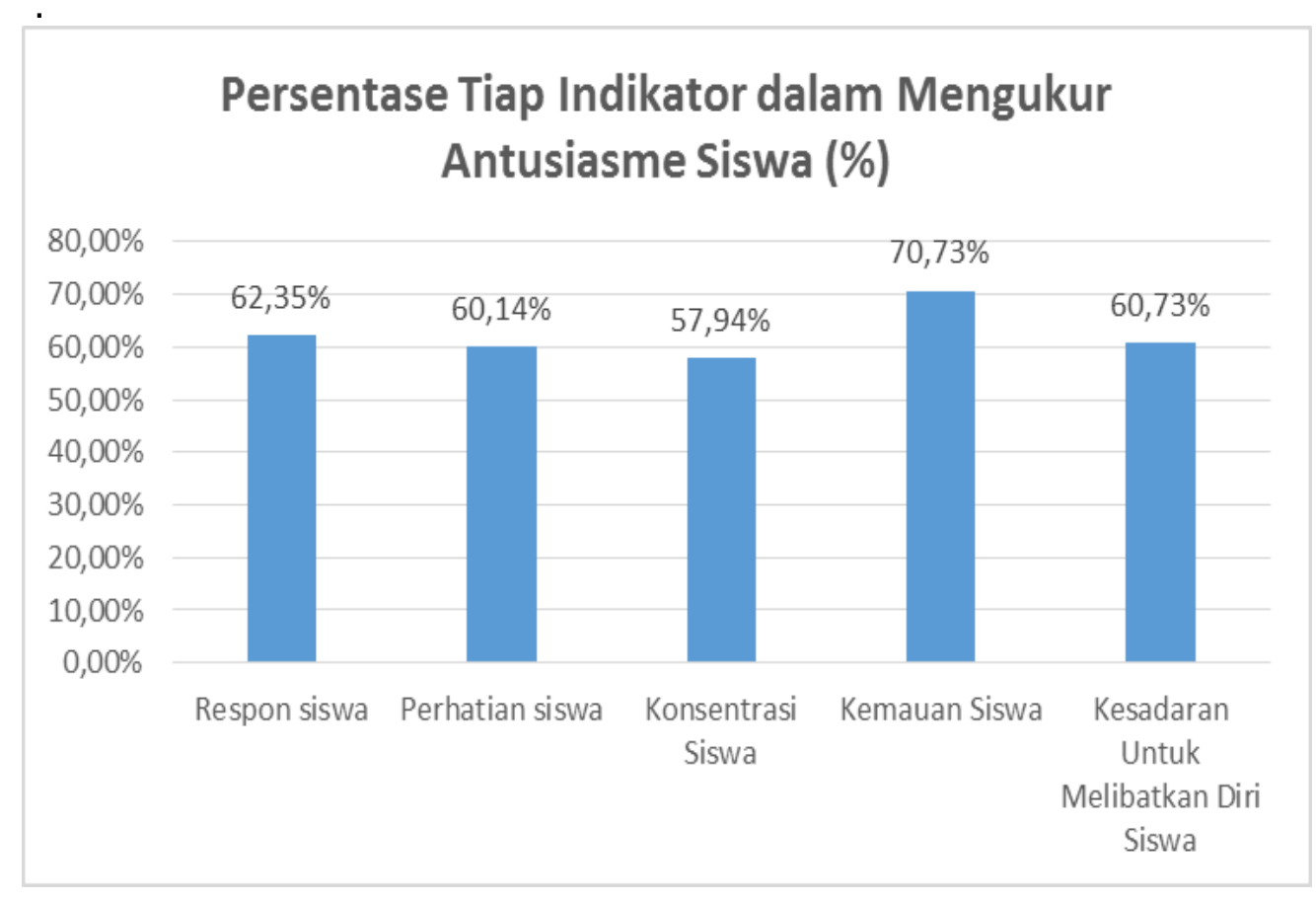

Gambar 2. Persentase tiap indikator dalam mengukur antusiasme siswa.

Antusiasme siswa diukur berdasarkan beberapa indikator yaitu respon, perhatian, konsentrasi, kemauan, dan kesadaran untuk melibatkan diri (Afdhal, 2015: 196). Indikator antusiasme yang pertama adalah respon siswa. Berdasarkan hasil yang diperoleh bahwa siswa memiliki aspek respon 62,35\%. Respon siswa merupakan tanggapan dan reaksi dari siswa terhadap pengkondisian pembelajaran yang telah dilakukan. Ada dua aspek respon siswa dalam pembelajaran yaitu aspek tanggapan dan reaksi. Aspek tanggapan meliputi 
antusias, rasa, dan perhatian. Sedangkan aspek reaksi meliputi kepuasan, keingintahuan dan senang (Bistari, 2017: 19). Indikator respon dalam mengukur antusiasme sebesar $62,35 \%$ termasuk kategori sedang. Persentase tersebut didasarkan pada pengisian angket antusiasme siswa dengan pertanyaan yang mengacu pada respon siswa, seperti adanya rasa puas, senang, bersemangat, dan rasa ingin mengulang kembali ketika mengerjakan soal trigonometri melalui Quizizz. Berdasarkan hasil tersebut, dapat diartikan bahwa penggunaan Quizizz akan membuat siswa senang dalam mengerjakan soal trigonometri dan tidak merasa bosan dalam pengerjaannya. Hal ini dikarenakan Quizizz memiliki karakteristik bermainnya seperti avatar, tema, meme, dan musik yang dapat menghibur siswa dalam proses pengerjaan soal. Hal ini sejalan dengan penelitian Basuki \& Hidayati (2019) yang menunjukkan bahwa Quizizz membawa kemajuan yang luar biasa, Quizizz dianggap menarik, membuat ketagihan dan memotivasi siswa untuk belajar dan mencapai hasil yang lebih baik.

Indikator yang kedua adalah perhatian siswa. Menurut Afdhal (2015: 196) siswa dikatakan mempunyai perhatian terhadap pembelajaran jika siswa memperhatikan penjelasan materi yang diberikan guru serta memperhatikan proses penyelesaian soal yang diberikan oleh guru. Indikator aspek perhatian meliputi adanya kemauan untuk memperhatikan seluruh langkah pengerjaan soal dengan menggunakan Quizizz serta kemauan untuk memperhatikan tiap butir soal. Bentuk perhatian yang diberikan oleh siswa ketika pengerjaan soal menggunakan Quizizz dapat dilihat dari kemauan siswa untuk memahami sistem pengerjaan soal, memperhatikan butir-butir soal, tidak melakukan kegiatan lain saat pengerjaan, serta kemandirian siswa saat pengerjaan soal. Aspek perhatian dalam indikator antusiasme ini termasuk kategori sedang yaitu sebesar 60,14\%. Persentase tersebut didasarkan pada pengisian angket antusiasme dengan mengacu pada pertanyaan terkait indikator perhatian yang diisi oleh siswa. Memperhatikan merupakan suatu yang mudah dilakukan oleh siswa. Namun siswa tak akan memperhatikan jika tidak ada motivasi atau dorongan dari diri siswa. Maka seorang guru harus mampu membangkitkan motivasi siswa terutama ketika pembelajaran maupun ketika evaluasi pembelajaran. Berdasarkan penelitian ini perhatian siswa memiliki kategori sedang dalam evaluasi pembelajaran menggunakan Quizizz. Hal itu menunjukkan bahwa penggunaan Quizizz untuk evaluasi belajar cukup membangkitkan motivasi siswa dalam mengerjakan soal yang diujikan, dikarenakan adanya papan peringkat yang menunjukkan skor masing-masing siswa dan urutan peringkat siswa, membangkitkan semangat siswa untuk terus bersaing dan mengerjakan soal dengan cepat dan teliti.

Menurut Nuryana \& Purwanto (2010: 89) salah satu faktor penting yang dapat membawa keberhasilan siswa dalam mencapai tujuan pembelajarannya adalah konsentrasi yang baik. Konsentrasi siswa adalah indikator antusiasme yang ketiga. Berdasarkan hasil angket dengan mengacu pada pertanyaan terkait indikator konsentrasi yang diisi siswa, konsentrasi mempunyai persentase 57,94\%. Persentase tersebut termasuk kategori sedang, namun perolehan tersebut merupakan perolehan terendah dalam indikator antusiasme pengerjaan soal trigonometri melalui platform Quizizz. 


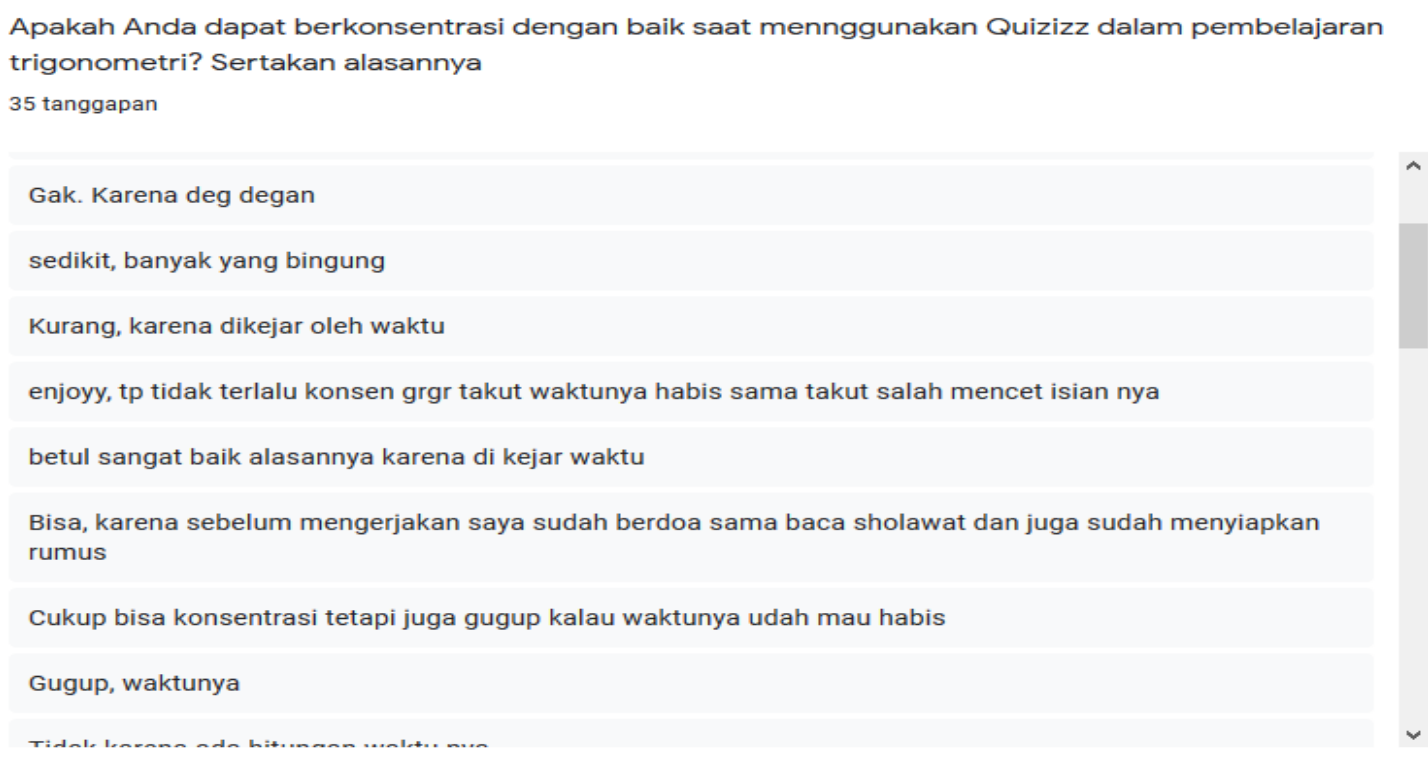

Gambar 3. Kuesioner konsentrasi siswa

Merujuk pada Gambar 3 yang merupakan hasil kuesioner konsentrasi siswa, hal ini dikarenakan siswa kurang bisa berkonsentrasi apabila saat pengerjaan tiap butir soal diberi batasan waktu. Siswa lebih konsentrasi jika pengerjaan soal tidak ada batasan waktu untuk tiap butir soal sehingga dengan begitu siswa akan mengerjakan soal dengan baik dan teliti. Hal ini sesuai dengan hasil penelitian Nusufi (2016) mengatakan bahwa konsentrasi merupakan kemampuan untuk memusatkan perhatian pada tugas dengan tidak terganggu oleh stimuli yang bersifat internal maupun eksternal sedangkan pelaksanaannya mengacu pada dimensi yang luas dan pemusatan pada tugas-tugas tertentu. Oleh sebab itu, dapat disimpulkan bahwa konsentrasi adalah usaha memusatkan perhatian terhadap sesuatu dengan mengabaikan hal lain yang mengganggu.

Indikator keempat adalah kemauan siswa. Kemauan ini meliputi kemampuan untuk segera mengerjakan soal trigonometri melalui Quizizz, kemauan untuk mengerjakan dengan cepat dan tepat saat mengerjakan soal trigonometri menggunakan Quizizz. Kemauan ini juga dapat dilihat dari ketertarikan serta rasa semangat siswa dalam mengerjarkan soal trigonometri menggunakan Quizizz. Berdasarkan hasil angket penelitian dengan pertanyaan yang mengacu pada indikator kemauan, memperoleh nilai tertinggi daripada indikator yang lainnya yaitu sebesar 70,73\%. 

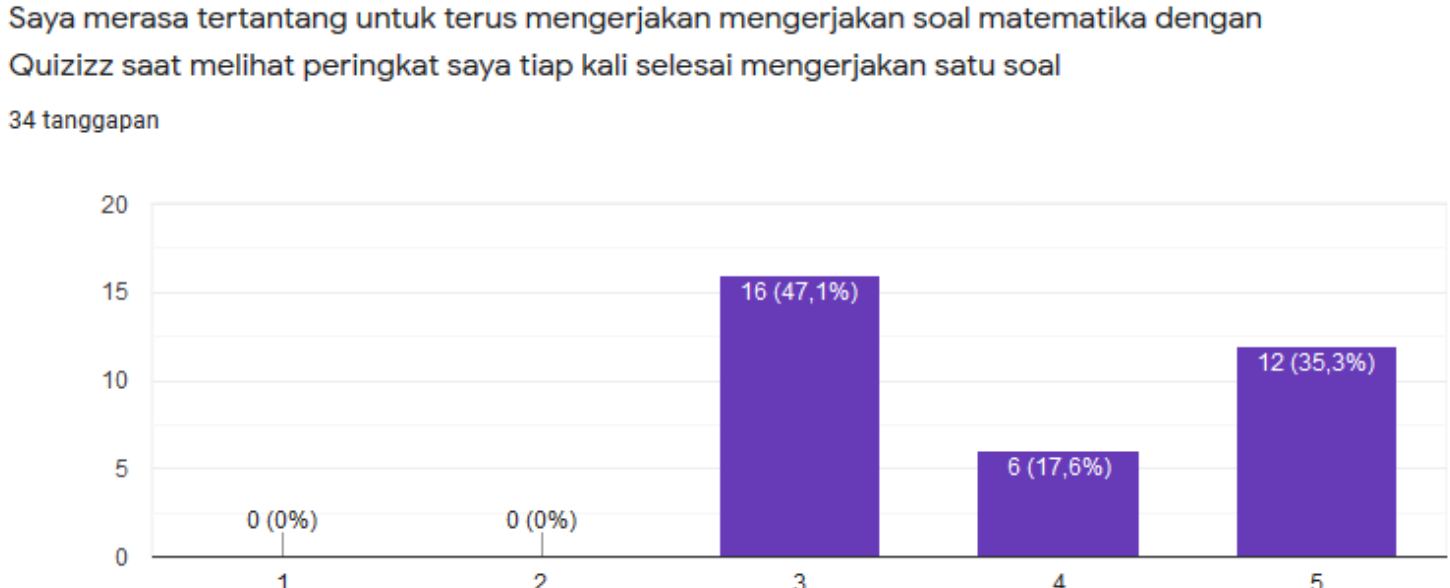

Gambar 4. Kuesioner kemauan siswa

Berdasarkan data pada Gambar 4 tersebut menunjukkan bahwa kemauan siswa dalam evaluasi belajar menggunakan Quizizz dinilai tinggi, hal ini dikarenakan adanya papan peringkat yang ditampilkan, siswa merasa termotivasi untuk bersaing dengan teman lainnya dan segera mengerjakan dengan cepat dan tepat setiap kali selesai mengerjakan satu soal. Hal ini sejalan dengan penelitian Afero \& Adman (2016) yang menunjukkan bahwa kemauan menduduki skor tertinggi yang menunjukkan bahwa keinginan siswa dalam belajar harus diatur oleh dirinya sendiri tanpa ada paksaan dari siapapun.

Indikator terakhir adalah kesadaran untuk melibatkan diri. Kesadaran ini meliputi kesadaran untuk belajar terlebih dahulu sebelum mengerjakan soal yang diujikan, kesadaran untuk mencari informasi dalam penggunaan Quizizz, serta rasa tertarik dalam pengerjaan soal selanjutnya. Pada penelitian ini diperoleh persentase sebesar 60,75\%. Perolehan tersebut masuk dalam kategori sedang yang berarti kesadaran siswa untuk melibatkan diri dalam evaluasi pembelajaran dinilai cukup baik dikarenakan siswa merasa bahwa evaluasi pembelajaran tersebut sangatlah penting sehingga perlu belajar terlebih dahulu sebelum mengerjakan soal yang diujikan. Menurut Fahmi (2013) faktor kesadaran dan tanggung jawab individual siswa merupakan faktor penting karena siswa akan aktif dalam memilih, merencanakan, melaksanakan dan mempertanggungjawabkan strategi yang dipakainya untuk mencapai keberhasilan. 


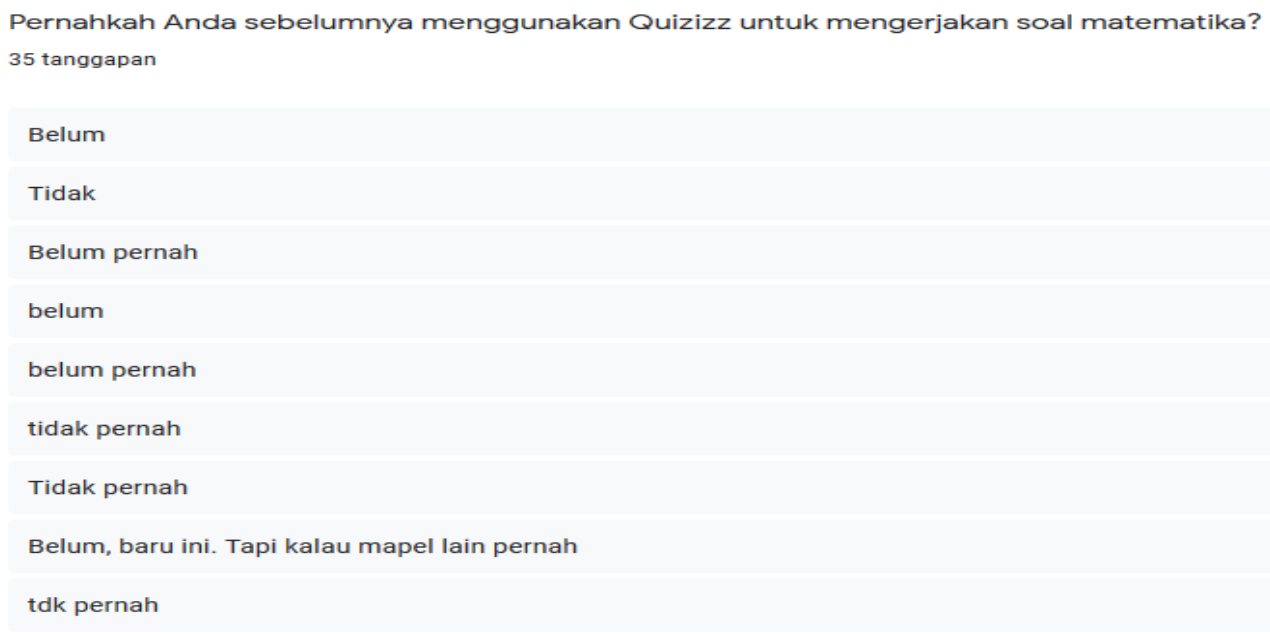

Gambar 5. Kuesioner penggunaan Quizizz

Berdasarkan hasil kuesioner penggunaan Quizizz pada Gambar 5 didapatkan, penggunaan Quizizz sebagai alat evaluasi belajar di kelas XI MIPA 4 SMA Negeri Tahunan merupakan suatu hal yang baru bagi mereka dalam evaluasi pembelajaran matematika, sehingga peneliti melakukan kegiatan latihan teknik penggunaan Quizizz bersama siswa terlebih dahulu, sehingga pelaksanaan evaluasi belajar nantinya berjalan dengan lancar karena siswa sudah mengerti teknis penggunaannya.

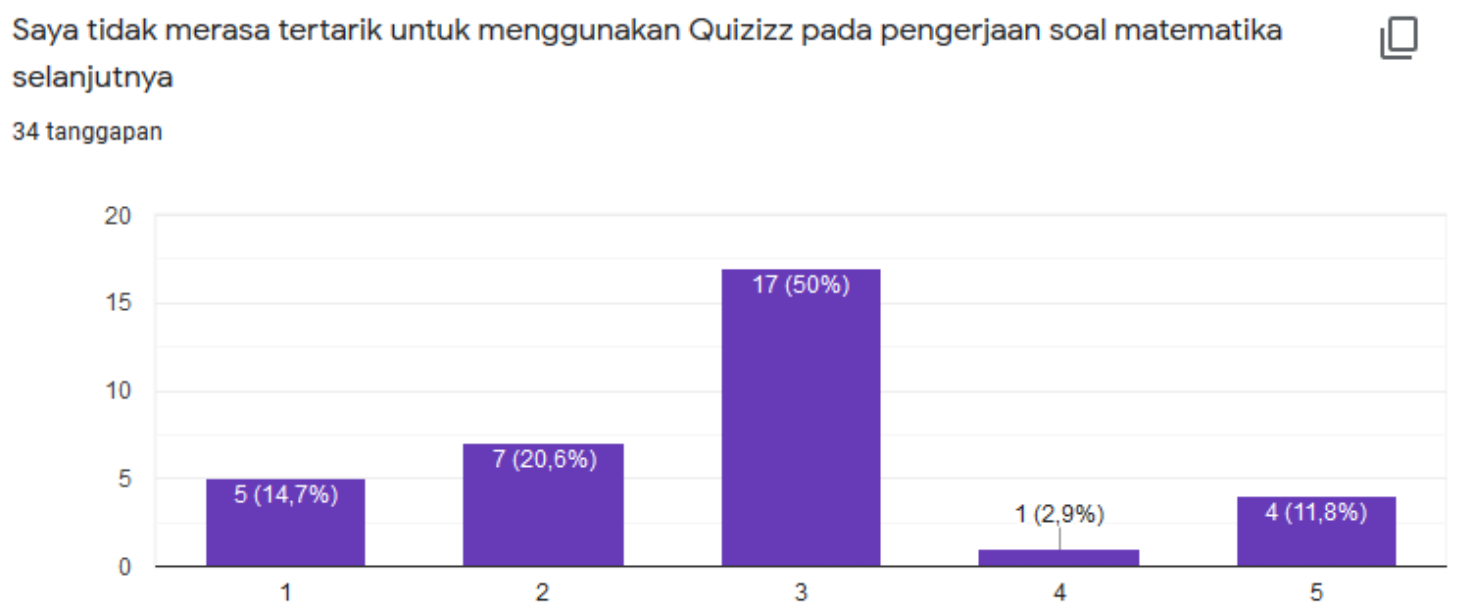

Gambar 6. Kuesioner kesadaran untuk melibatkan diri

Mayoritas siswa merasa tertarik untuk mengerjakan soal selanjutnya menggunakan Quizizz, hal ini didukung hasil kuesioner siswa pada Gambar 6 yang tidak menyetujui terkait pernyataan dalam kuesioner sehingga dapat diartikan mayoritas siswa tertarik menggunakan Quizizz dalam evaluasi pembelajaran matematika selanjutnya. 


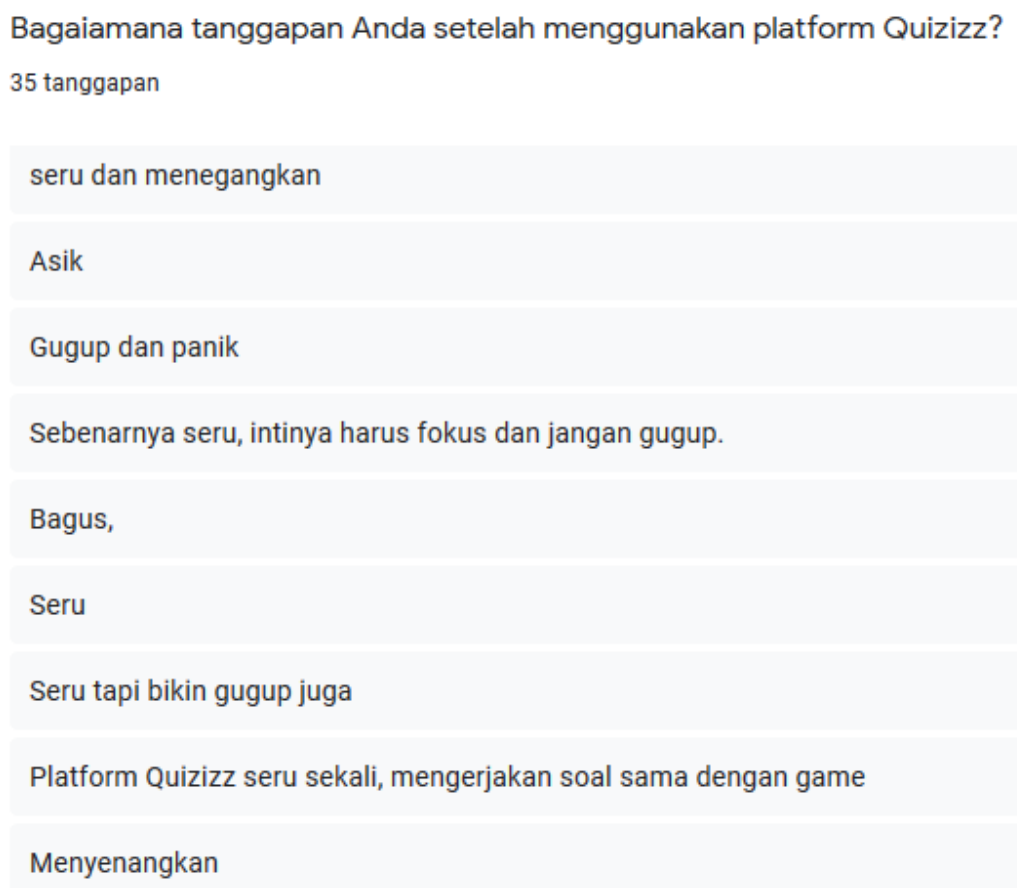

Gambar 7. Kuesioner setelah penggunaan Quizizz

Berdasarkan hasil respon siswa pada Gambar 7, evaluasi belajar menggunakan Quizizz dirasa seperti bermain game sehingga terasa seru dan menegangkan.

Uraian tersebut menunjukkan bahwa indikator antusiasme siswa memiliki persentase yang berbeda-beda dalam mempengaruhi besarnya antusiasme siswa dalam evaluasi belajar melalui platform Quizizz. Setiap indikator mempunyai hasil dengan kriteria cukup dan tinggi. Namun Indikator konsentrasi siswa menempati persentase terendah daripada indikator yang lainnya dikarenakan oleh beberapa faktor yaitu adanya keterbatasan waktu dalam pengerjaan soal sehingga fokus siswa kurang maksimal.

Berdasarkan perhitungan dari hasil angket dalam penelitian mendapat skor keseluruhan 21.221 dan apabila dipersentasekan terdapat $62,38 \%$ pemilih positif. Sehingga dalam angket tergolong kategori sedang. Dapat diartikan bahwa dari hasil penggolongan ranting, siswa-siswi kelas XI MIPA 4 SMA Negeri 1 Tahunan Jepara tahun ajaran 2020/2021 memiliki antusiasme yang cukup baik dalam penggunaan Quizizz sebagai alat evaluasi belajar dikarenakan dengan menggunakan Quizizz siswa merasa lebih bersemangat dalam melaksanakan evaluasi karena fiturnya yang menarik perhatian siswa, selain itu dengan adanya papan peringkat yang menunjukkan hasil kinerja siswa menjadikan siswa lebih termotivasi untuk mencapai hasil evaluasi yang tinggi.

Hasil ini sejalan dengan penelitian yang dilakukan oleh Basuki \& Hidayati (2019) yang menunjukkan bahwa Quizizz membawa kemajuan yang luar biasa, Quizizz dianggap menarik, membuat ketagihan dan memotivasi siswa untuk 
belajar dan mencapai hasil yang lebih baik. Selain itu, juga didukung dalam penelitian Zhao (2019) menunjukkan bahwa penggunaan Quizizz dapat meningkatkan pengalaman siswa, siswa setuju bahwa Quizizz mudah digunakan, latihan menggunakan Quizizz menyenangkan, membantu mereka mereview materi pelajaran, dan merangsang minat mereka dalam belajar akuntansi.

Kelebihan penggunaan platform Quizizz sebagai evaluasi pembelajaran dalam penelitian ini di antaranya: (1) Siswa dapat mengetahui poin yang didapatkannya, (2) Meminimalisir adanya kecurangan, dikarenakan dalam Quizizz soal yang ada otomatis telah diacak, sehingga setiap siswa mendapatkan soal yang berbeda satu dengan yang lainnya, (3) Siswa dapat mengetahui peringkat yang didapat sesaat setelah mengerjakan satu soal, (4) Terdapat review question di akhir pengerjaan question. Selain terdapat kelebihan, dalam pengerjaan evaluasi menggunakan platform Quizizz juga terdapat kekurangan, di antaranya: (1) Dibutuhkannya jaringan internet dalam pengerjaannya, (2) Siswa mudah merasa cemas saat pengerjaan, (3) Siswa diharuskan untuk pintar dalam memanajemen waktu juga teliti dalam pengerjaannya, karena dalam sistem penilaian Quizizz terhitung dari waktu pengerjaan dan kebenaran pengerjaan, semakin cepat serta tepat seorang siswa dalam pengerjaannya, maka akan memperoleh nilai yang semakin tinggi.

Berdasarkan hasil penelitian tersebut, dapat dikemukakan implikasi secara teoritis yaitu pemilihan media evaluasi berpengaruh terhadap antusiasme siswa dalam mengerjakan soal yang nantinya akan berpengaruh juga terhadap hasil belajar siswa. Hal ini sejalan dengan penelitian yang dilakukan oleh Kurniawan \& Huda (2020) mengatakan bahwa penggunaan Quizizz sebagai latihan soal berpengaruh positif terhadap hasil belajar karena pengunaan Quizizz menstimulus siswa memahami soal lebih baik daripada soal berbasis buku teks. Hasil penelitian ini berimplikasi bahwa guru perlu melakukan variasi pembelajaran terutama dalam hal evaluasi pembelajaran untuk mendukung terciptanya suasana belajar yang lebih menyenangkan ,tidak monoton, serta berbasis teknologi. Jadi, berdasarkan hasil data yang sudah dilakukan analisis dan merujuk teori dan penelitian sebelumnya dapat disimpulkan bahwa penggunaan Quizizz sebagai evaluasi belajar dapat menjadi alternatif guru dalam meningkatkan antusiasme siswa dalam evaluasi pembelajaran.

\section{KESIMPULAN DAN SARAN}

Berdasarkan hasil penelitian dapat disimpulkan bahwa antusiasme siswa yang mencakup respon, perhatian, konsentrasi, kemauan, dan kesadaran untuk melibatkan diri dalam evaluasi belajar pada materi trigonometri melalui platform Quizizz tergolong cukup baik dengan persentase 62,38\%. Sehingga dalam angket tergolong kategori sedang. Dapat diartikan bahwa dari hasil penggolongan ranting, siswa-siswi kelas XI MIPA 4 SMA Negeri 1 Tahunan Jepara tahun ajaran 2020/2021 memiliki antusiasme yang cukup baik dalam penggunaan Quizizz sebagai alat evaluasi belajar dikarenakan dengan menggunakan Quizizz siswa merasa lebih bersemangat dalam melaksanakan evaluasi karena fiturnya yang menarik perhatian siswa, selain itu dengan adanya papan peringkat yang menunjukkan hasil kinerja siswa menjadikan siswa lebih termotivasi untuk mencapai hasil evaluasi yang tinggi. Sehingga dapat disimpulkan bahwa platform 
Quizizz dapat menjadi alternatif guru dalam melaksanakan evaluasi hasil belajar siswa guna meningkatkan antusiasme siswa dalam evaluasi belajar, serta menciptakan suasana evaluasi yang menyenangkan dan menarik untuk diikuti siswa. Hal ini sesuai dengan pernyataan Wahyudi, Rufiana, \& Nurhidayah (2020:106) yang menyatakan aplikasi online Quizizz dapat dijadikan sebagai alternatif penilaian pembelajaran yang berpusat pada siswa, terutama untuk menunjang pembelajaran di era pandemi.

Berdasarkan hasil penelitian, peneliti memberikan saran yaitu (1) Bagi guru yang ingin menggunakan Quizizz sebagai evaluasi belajar untuk siswanya diharapkan dalam pemberian batas waktu untuk setiap soal disesuaikan dengan kategori soal yang diberikan, (2) Bagi siswa sebelum melakukan evaluasi menggunakan Quizizz untuk berlatih terlebih dahulu mengerjakan soal dengan batas waktu agar nantinya saat mendapat soal yang terdapat batas waktu akan lebih terbiasa serta terhindar dari rasa takut dan cemas dalam pengerjaannya dan, (3)Bagi peneliti selanjutnya, hasil penelitian ini diharapkan dapat dijadikan referensi dalam melakukan penelitian selanjutnya dengan berbagai aspek lainnya.

\section{UCAPAN TERIMA KASIH}

Ucapan terima kasih peneliti tujukan kepada Ibu Fadhilah Rahmawati, M.Pd selaku dosen pembimbing, Ibu Sri Endah Wahyuni, S.Pd selaku guru matematika kelas XI MIPA 4 SMA Negeri 1 Tahunan yang telah bersedia menjadikan kelasnya sebagai lokasi dan pusat penelitian ini. Atas segala kontribusi dan bantuannya dalam melancarkan proses penelitian ini sehingga penelitian ini dapat disusun dengan temuan-temuan penelitian di lapangan yang nantinya penulis harapkan agar dapat dijadikan sebagai bahan masukan untuk kelas yang diampu beliau. Dan tentunya tak lupa, kami ucapkan terima kasih untuk seluruh siswa kelas XI MIPA 4 SMA Negeri 1 Tahunan Jepara atas partisipasinya dalam menyukseskan penelitian ini.

\section{DAFTAR PUSTAKA}

Abi Hamid, M. (2016). Pengembangan Instrumen Penilaian Hasil Belajar Siswa Berbasis TIK pada Pembelajaran Dasar Listrik Elektronika. VOLT: Jurnal Ilmiah Pendidikan Teknik Elektro, 1(1), 37-46.

Afdhal, M. (2015). Menumbuhkan Kemampuan Berpikir Kritis Matematis dan Antusiasme Belajar Melalui Pendekatan Reciprocal Teaching. Makalah Disajikan Dalam Seminar Nasional Matematika Dan Pendidikan Matematika UNY, 193-200.

Afero, B., \& Adman, A. (2016). Peran Kecerdasan Emosional Sebagai Faktor yang Mempengaruhi Kemandirian Belajar Siswa. Jurnal Pendidikan Manajemen Perkantoran, 1(1), 215. https://doi.org/10.17509/jpm.v1i1.3390

Basuki, Y., \& Hidayati, Y. (2019). Kahoot! or Quizizz: the Students' Perspectives. ELLiC 2019: Proceedings of the 3rd English Language and Literature International Conference, ELLiC, 27th April 2019, Semarang, Indonesia, 202. 
European Alliance for Innovation.

Bistari, B. (2017). Konsep dan indikator pembelajaran efektif. Jurnal Kajian Pembelajaran Dan Keilmuan, 1(2), 13-20.

Elis Ratna Wulan, E., \& Rusdiana, A. (2015). Evaluasi pembelajaran. Bandung: Pustaka Setia.

Fahmi, Z. (2013). Indikator Pembelajaran Aktif Dalam Konteks Pengimplementasian Pendekatan Pembelajaran Aktif, Kreatif, Efektif, Dan Menyenangkan (Pakem). Al-Ta Lim Journal, 20(1), 278-284. https://doi.org/10.15548/jt.v20i1.24

Henry, S. (2010). Cerdas dengan Game. Jakarta: PT Gramedia Pustaka Utama.

Ju, S. Y., \& Adam, Z. (2018). Implementing Quizizz as game based learning in the Arabic classroom. European Journal of Social Science Education and Research, 5(1), 194-198.

Kuncahyono, K., Suwandayani, B. I., \& Muzakki, A. (2020). Aplikasi E-Test "That Quiz" sebagai Digitalisasi Keterampilan Pembelajaran Abad 21 di Sekolah Indonesia Bangkok. Lectura: Jurnal Pendidikan, 11(2), 153-166.

Kurniawan, A. S., \& Prastowo, P. (2017). Antusiasme Belajar Siswa Kelas X Ilmu Pengetahuan Bahasa Pada Lintas Minat Biologi di MAN 2 Model Medan. Jurnal Pelita Pendidikan, 5(1), 108-117.

Kurniawan, M. C. D., \& Huda, M. M. (2020). Pengaruh Penggunaan Quizizz Sebagai Latihan Soal Terhadap Hasil Belajar Siswa Kelas V SD. Jurnal Pena Karakter (Jurnal Pendidikan Anak Dan Karakter), 3(1), 37-41.

Mahirah, B. (2017). Evaluasi Belajar Peserta Didik (Siswa). Idaarah: Jurnal Manajemen Pendidikan, 1(2), 257-267.

Nuryana, A., \& Purwanto, S. (2010). Efektivitas brain gym dalam meningkatkan konsentrasi belajar pada anak. Ilmiah Berkala Psikologi, VOl.12 No., 88-98.

Nusufi, M. (2016). Melatih Konsentrasi Dalam Olahraga. Jurnal Ilmu Keolahragaan, 15(2), 54-61.

Purba, L. S. L. (2020). The effectiveness of the quizizz interactive quiz media as an online learning evaluation of physics chemistry 1 to improve student learning outcomes. Journal of Physics: Conference Series, 1567(2), 22039. IOP Publishing.

Putra, R. W. Y., \& Anggraini, R. (2016). Pengembangan Bahan Ajar Materi Trigonometri Berbantuan Software iMindMap pada Siswa SMA. Al-Jabar: Jurnal Pendidikan Matematika, 7(1), 39-47.

Rahayu, I. S. D., \& Purnawarman, P. (2019). The Use of Quizizz in Improving Students' Grammar Understanding through Self-Assessment. 254(Conaplin 2018), 102-106. https://doi.org/10.2991/conaplin-18.2019.235

Salmina, M., \& Adyansyah, F. (2017). Analisis Kualitas Soal Ujian Matematika Semester Genap Kelas XI sma Inshafuddin Kota Banda Aceh. Numeracy, 4(1), 37-47. 
Samuel, D. (2015). Antusiasme guru dalam program pengembangan kompetensi pedagogik dan determinannya. Kelola: Jurnal Manajemen Pendidikan, 2(2), 214-220.

Sari, N., Sunarno, W., \& Sarwanto, S. (2018). Analisis Motivasi Belajar Siswa dalam Pembelajaran Fisika Sekolah Menengah Atas. Jurnal Pendidikan Dan Kebudayaan, 3(1), 17-32. https://doi.org/10.24832/jpnk.v3i1.591

Tiwijayanti, R., \& Pramono, M. (2020). Antusiasme Siswa Remaja terhadap Upaya Pelestarian Budaya Melalui Pengenalan Permainan Olahraga Tradisional di Museum Negeri Jawa Timur MPU Tantular. Jurnal Kesehatan Olahraga, 8(3), 105-110.

Wihartanti, L. V., Wibawa, R. P., Astuti, R. I., \& Pangestu, B. A. (2019). Penggunaan aplikasi quizizz berbasis smartphone dalam membangun kemampuan berpikir kritis mahasiswa. Seminar Nasional Pendidikan Dan Pembelajaran $2019,362-368$.

Zhao, F. (2019). Using Quizizz to Integrate Fun Multiplayer Activity in the Accounting Classroom. International Journal of Higher Education, 8(1), 37-43. 